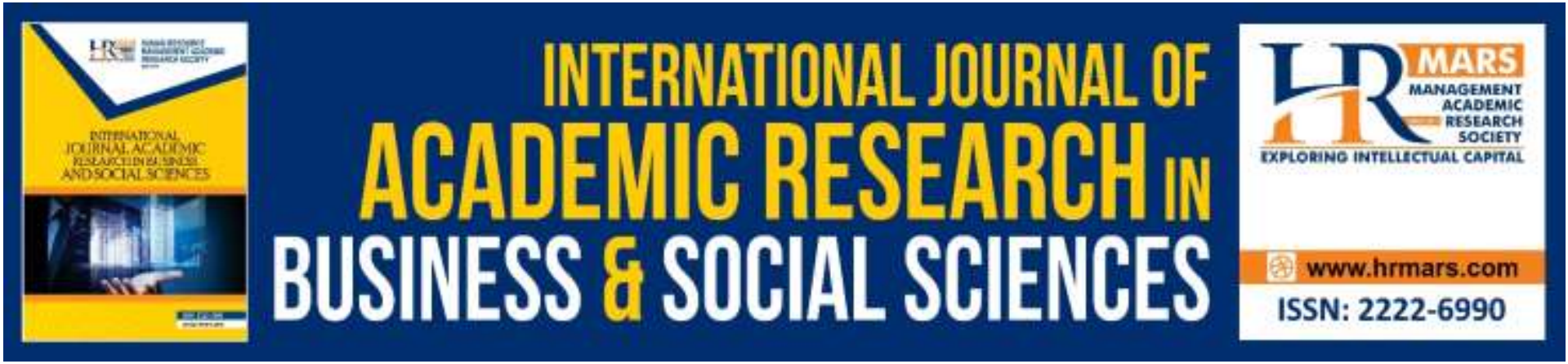

\title{
A Review on Counterproductive Work Behavior (CWB) and EVLN Coping Strategy Model amongst Flight Attendants
}

Mohd Ariffin Siti Zubaidah, Siew Imm Ng, Jo Ann Ho and Sambasivan Murali

To Link this Article:http://dx.doi.org/10.6007/IJARBSS/v9-i10/6468

DOI: 10.6007/IJARBSS/v9-i10/6468

Received: 10 September 2019, Revised: 20 September 2019, Accepted: 01 October 2019

Published Online: 24 Oct 2019

In-Text Citation: (Zubaidah, Ng, Ho, \& Murali, 2019)

To Cite this Article: Zubaidah, M. A. S., Ng, S. I., Ho, J. A., \& Murali, S. (2019). A Review on Counterproductive Work Behavior (CWB) and EVLN Coping Strategy Model amongst Flight Attendants. International Journal of Academic Research in Business and Social Sciences, 9(10), 118-138.

Copyright: (c) 2019 The Author(s)

Published by Human Resource Management Academic Research Society (www.hrmars.com)

This article is published under the Creative Commons Attribution (CC BY 4.0) license. Anyone may reproduce, distribute, translate and create derivative works of this article (for both commercial and non-commercial purposes), subject to full attribution to the original publication and authors. The full terms of this license may be seen

at: http://creativecommons.org/licences/by/4.0/legalcode

Vol. 9, No. 10, 2019, Pg. 118 - 138

http://hrmars.com/index.php/pages/detail/IJARBSS

JOURNAL HOMEPAGE

Full Terms \& Conditions of access and use can be found at http://hrmars.com/index.php/pages/detail/publication-ethics 


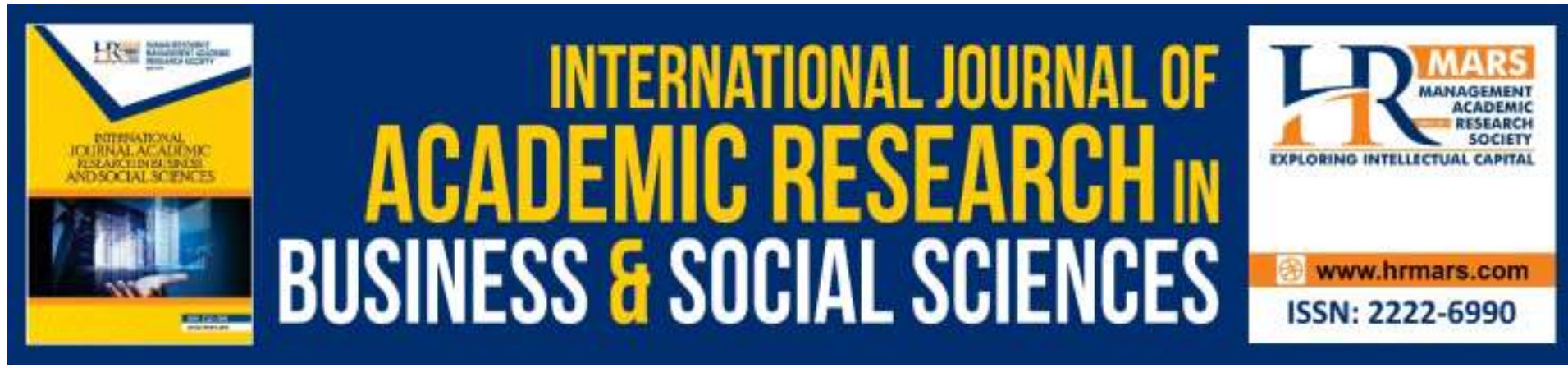

\title{
A Review on Counterproductive Work Behavior (CWB) and EVLN Coping Strategy Model amongst Flight Attendants
}

\section{Mohd Ariffin Siti Zubaidaha, Siew Imm Ng${ }^{b}$, Jo Ann Hoc , and Sambasivan Muralid}

aPutra Business School, Universiti Putra Malaysia, 43400, Serdang, Selangor Malaysia, bepartment of Management and Marketing, Faculty of Economics and Management, Universiti Putra Malaysia, 43400 Serdang, Selangor, Malaysia, 'Department of

Management and Marketing, Faculty of Economics and Management

Universiti Putra Malaysia, 43400 Serdang, Selangor, Malaysia, ${ }^{\mathrm{d}}$ Taylor's Business School, Taylor's University Lakeside Campus

Email: sitizubaid71@gmail.com,imm_ns@upm.edu.my,ann_hj@upm.edu.my, murali.sambasivan@taylors.edu.my

\begin{abstract}
This is a review on counterproductive work behavior, a variable that was prompted by the trends of strikes organized by flight attendants. The review begins by understanding what counterproductive work behavior is, its definitions, typologies, and antecedents of counterproductive work behavior. This is followed by highlighting the theoretical gaps of counterproductive work behavior, leading to conceptualizing counterproductive work behavior using Hirschman's Model of EVLN with an extension of silence. Hirschman's EVLN addresses the challenges in identifying the non-exhaustive list of CWB as was defined and classified by past studies. Secondly, in an attempt to understand how employees coped with the organizational changes induced by organization experiencing financial distress, made Hirschman's EVLN as one typology of CWB a relevant choice given its ability in highlighting the existence of tangible act of counterproductive work behavior such as turnover intention and voice, as well as well as intangible act of deviant behavior such as disloyalty, neglect and silence that could not possibly be captured through organization's formal communication channel.
\end{abstract}

Keywords: Counterproductive Work Behavior, Hirschman's EVLN, Deviant Behavior.

\section{Introduction}

The surge in CWB studies goes back to the era of Industrial Revolution (Klotz and Buckley, 2013). Citing Hollinger and Langton (2006) and Govoni (1992), the financial cost of CWB lies between 17.6 billion dollars to 200 billion dollars (Griep, Vantilborgh, Jones, 2018). Galperin \& Burke (2006) mentioned expenses linked to CWBs include a tarnished reputation, 
deteriorating employee performance, and insurance losses (Cohen, 2016). Workplace deviants were also driven by reactions to changes in technology (Klotz and Buckley, 2013). The escalation of employee misconducts are results from economic volatility, intensified industry competition, and organizations' growing inclinations towards survival strategies such as mergers and consolidation, restructuring and downsizing (Hussain, Sia, and Mishra, 2014).

\section{Definition of Counterproductive Work Behavior}

Bennet and Robinson (2000) viewed CWB as employees' conduct in workplace that were often underobserved and unaccounted for (Raman, et al, 2016). O'Boyle, Forsyth, \& O'Boyle (2011) defined CWB as activities that intentionally impair the organization or cause harm to employees (Cohen, 2016). Baron \& Richardson (1994) and Robinson \& Bennet (1995a) viewed CWB as deliberations and conducts that breached explicit and implied rules about expected behaviors within an organization, compromising the overall wellbeing of organizational members, and jeopardizing the interest of the organization as a whole (Brimecombe, Magnusen, and Bunds, 2014). CWB is described as a series of conducts that are harmful to the organization by upsetting the organization's overall operations and employees, leading to distressing overall operational efficiency (Anjum and Parvez, 2013).

Anderson and Pearson (1999) presented incivility as another form of CWB, defined as individual's actions or behavior that deviate from workplace norms or standards. It is low in strength and the intent is unclear in harming its target (Sayers, Sears, Kelly, and Harbke, 2011). Uncivil behaviors include rude, discourteous, or being inconsiderate towards others (Sayers, Sears, Kelly, and Harbke, 2011). A non-exhaustive list of CWB can be triggered, as claimed by Fox \& Spector (2005) from an extensive and varied range of reasons as well as from systematic, severe, abusive, to series of workplace incivility (Raman, et al, 2016). Robinson \& Bennet (1995) described CWB as sabotage, loafing, daydreaming, theft, absenteeism, and vandalism (Dischner, 2015).

\section{Typologies of Counterproductive Work Behavior (CWB) proposed by past scholars}

CWB can be seen from individual as well as collective level. Robinson (2008) observed the increasing number of researchers that moved away from the individual level of counterproductive work behavior, and centered on ascertaining predictors of group deviance act (Kelloway, Francis, Prosser, Cameron, 2010). Tools down, work-to-rule, work slow campaign, forged medical leave are examples of behaviors that are relevant to industrial relations issues (Kelloway, Francis, Prosser, Cameron, 2010). CWB can be viewed from the severity of the act, from gossiping during work to physical assault or sexual harrassment (Kelloway, Francis, Prosser, Cameron, 2010).

Deviant behavior was described according to target, causing harm to individuals (interpersonal deviance) or organization (organizational deviance) (Kelloway, Francis, Prosser, Cameron, 2010). Marcus \& Schuler (2004) termed CWB as conducts that contravene the lawful interest of an organization by causing harm to employees (CWB-I) and organization (CWB-O) as a whole (Raman, et al. , 2016). CWB-O is further described by Fox et al (2001); Dalal, (2005); and Spector and Fox, (2005) as the most deviant behavior that influence organizational's success or failure (Bai, Lin, and Wang, 2016). 
CWB can be analyzed from symmetric and asymmetric lens. Many researches have predominantly focused on symmetric outcomes of discretionary work behaviour, that is, explaining the antecedents and nature of CWB (Reynolds, Shoss, and Jundt, 2015). This approach in defining CWB serves to explain individual intentions and behaviors, how CWBs impact organizational members, and how CWBs impact the organization itself (Brimecombe, Magnusen, and Bunds, 2013). These three-prong view is also shared by Reynolds, et.al (2015) who emphasized the need to look at counterproductive work behaviour in an assymmetric way, where the outcome of CWB can also be seen as good or bad for different stakeholder (Reynolds, Shoss, and Jundt, 2015). Another example from assymmetric approach can be captured from employees' deliberate misconduct such as work slowdown, work-to-rule, and planned sick days (Kelloway, Francis, Prosser, Cameron, 2010) in an attempt to exhibit their job dissatisfaction over newly introduced policies affecting employees' overall working condition and benefits. Spector and Fox (2005 a,b) claimed that labelling these behaviours as counterproductive is a political decision (Kelloway, Francis, Prosser, Cameron, 2010). It was suggested that workplace deviant behavior is also an occurrence of multifaceted phenomenon that results from various antecedents (Hussain, Sia, and Mishra, 2014). Supporting the asymmetric view of CWB is Spector \& Fox $(2005 a, b)$ in explaining CWB can be viewed proactive or practical for the individual or group (Kelloway, Francis, Prosser, and Cameron, 2010).

From symmetric approach, CWB may be stemmed from individual characteristics that influence employees' decision to engage in deviant behaviors. From assymmetric approach, CWB can be encouraged, as suggested by Coccia (1998) through a toxic organization termed by their poor performance, inferior decision making, with unmanageable employee dissatisfaction, compounded by work stress caused by work overload that could have influenced employees' deviant behavior (Hussain, Sia, and Mishra, 2014). Fox, Spector, \& Miles (2001) suggested that CWB are also related to weak leadership (Brimecombe, Magnusen, and Bunds, 2013). The vaguesness in organization's vision and mission leading to employees' perceived job uncertainties, such as low probability of internal mobility and their perceived risk of unemployment (Brimecombe, Magnusen, and Bunds, 2013). As asserted by Marcus and Schuler (2004), these uncertainties were made worst when there are opportunities or platform readily available for employees to indulge in counterproductive work behavior. The opportunities include perceived group norms of general counterproductive work behaviors, anticipated group sanctions, such as protest or strikes, perceived organizational monitoring, organizational sanctions, organizational awareness of general counterproductive behavior and perceived unemployment risk (Brimecombe, Magnusen, and Bunds, 2013).

CWB can be constructive or destructive. Citing Warren (2003) who provides another typology almost similar to symmetric and asymmetric CWB where the positive and negative effect of Work Deviant Behavior (WDB) were both being considered (Hussain, Sia, and Mishra, 2014). However, Warren (2003) classified Work Deviant Behaviour into four categories, consisting of constructive comformity, destructive conformity, constructive deviance, and destructive deviance (Hussain, Sia, and Mishra, 2014), further suggesting the use of global standards 
termed as "hypernorms" for judging deviance. Warren (2003) defines workplace deviance as behavioral distinct from norms of reference groups (Hussain, Sia, and Mishra, 2014).

Robin \& Greenberg, (1998); and Vardi \& Weitz, 2004) had acknowledged that CWB is not solely associated with a specific class of profession, as CWB exist across all business organization as well at every level of employments, from interns, salaried, nonprofessionals and professionals, non-supervisory employees, and executive (Brimecombe, Magnusen, and Bunds, 2013). Similary, CWB can be associated with employees of blue collar as well as white collar profession (Anjum, and Parvez, 2013). High profile scandals such as Enron and Worldcom covered by major news media provide an illustration of the unethical behaviour by white collar profession (Cohen, 2016). Miller (1995) describe Nick Leeson who was a former derivatives, as one example of high profile CWB, who is responsible in causing the downfall of one of England's oldest financial establishment (Warren, 2003).

\section{Operational Definitions of Counterproductive Work Behavior}

Based on definitions and typologies and common keywords of Counterproductive Work Behavior captured from past studies, from symmetric and assymetric lens (Reynolds, Shoss, and Jundt, 2015); blue and white collar (Anjum and Parvez, 2013); individual and collective (Robinson, 2008; Anderson and Pearson, 1999); proactive and practical (Kelloway, Francis, Prosser, Cameron, 2010; Reynolds, Shoss, and Jundt, 2015); severity of the act (Kelloway, Francis, Prosser, Cameron, 2010), individual (CWB-I) and organization (CWB-O) (Marcus \& Schuler, 2004); constructive and destructive (Hussain, Sia, and Mishra, 2014), multifaceted phenomenon (Hussain, Sia, and Mishra, 2014); underobserved and unaccounted for (Bennet and Robinson, 2000), the operational definition of Counterproductive Work Behavior to be applied in this study in the context of airline industry is:

"Counterproductive work behavior is defined as a multifaceted phenomenon of boomerang effect stemming from individual or group across blue collar and white collar workers' intentional or undeliberated behavior reflecting incivility, that could be proactive and practical, constructive as well as destructive, underobserved and unaccounted for, but have detrimental effect to all stakeholders, and severe enough to cause distress to organization".

\section{Antecedents of Counterproductive Work Behavior}

There are at least seven predictors of CWB thus far, namely gender, family and work incivility, personality, emotional states, leadership styles, trust, and psychological contract breach. Baughman et al (2012) and Bowling \& Burns (2015) indicated that gender (male) was found to have strong effect on CWBs (Cohen, 2016). Based on a study using Work-Home Resource model, result indicated positive linkage of family incivility with CWB (Bai, Lin, and Wang, 2016).

Smith and Lilienfeld (2013) explained that Dark Triad personality consist of three interpersonnally maladaptive personality constructs, namely machiavellianism, narcissism, and psychopathy. Past studies indicated a weak to moderate association between dark triad personality and CWB, suggesting the absence of moderator and mediator (Cohen, 2016). Berry, Ones, and Sackett (2007) often use the Five Factor Model (Agreeableness, Conscientiousness, Neuroticism, Openness, Extraversion) as a personality predictor of CWB 
(Scherer, Baysinger, Zolynsky, and LeBreton, 2013). Scherer et al (2013)'s studies on the Big Five traits replicated previous findings of a negative association between agreeableness and conscientiousness and counterproductive work behavior. Similar study had found significant and positive correlation between Neuroticism and CWB (Scherer, Baysinger, Zolynsky, and LeBreton, 2013). Denollet (2005) stated that Type D individuals are more inclined to experience depression and anxiety (Kret, Denollet, Grezes, and Gelder, 2011). Type D Personality consist of two components. The first is negative affectivity that individual experience over time. Second component is the social inhibition, which is the inclination of individuals to suppress the negative affectivity due to fear of (Kret, Denollet, Grezes, and Gelder, 2011).

CWB is also a consequence of emotional states, such as dissatisfaction as claimed by Fatima et al (2012) and Muafi, (2011), and negative emotions as stated by Krisher, Penner \& Hunter (2010); and Khan, Peretti \& Quratulain (2010) (Anjum and Parvez, 2013). CWB is also argued to be a consequence of envy as maintained by Khan, Quratulain \& Peretti (2009) (Anjum and Parvez, 2013).

Schyns and Schilling (2013) claimed the sound linkage between destructive leadership and CWBs (Cohen, 2016). A study on dark triad personality or psychopath provides an explanation of the existence of psychopath personalities even within the leadership and management position. Hare (1999) argued that psychopaths are drawn to targeted organizations of which these psychopaths believed of the power, prestige, and financial gain they can potentially achieve from (Cohen, 2016). Smith and Lilienfeld (2013), Chiaburu, Munoz, and Gardner (2013) highlight the adaptive traits of psychopaths that allows them to have the capabilities in creating a false projection of success through treachery (Cohen, 2016). Schyns (2015) describes the intangibility of the psychopath traits make these psychopaths easily gone unnoticed given their capability in disguising their immoral acts through attractive charisma (Cohen, 2016).

Trust was conceptualized as faith and loyalty to the leader (Podsakoff, Mackenzie, Moorman, and Fetter, 1990). Organizational trust refers to global assessment of employees' perception towards their organization's level of trustworthiness (Shahnawaz and Goswami, 2011). Trust is easily taken back by the employees in time of recession, restructuring, downsizing, particularly when employees' perks and benefits are reduced (Shahnawaz and Goswami, 2011). Tan and Tan (2000) describe turnover intention and organizational commitment as the significant outcome of trust in organization (Shahnawaz and Goswami,, 2011). Similarly, Psychological Contract Breach was found to have a significant positive effect on employees' unethical behavior (Ning and Zhaoyi, 2017). The accumulation of Psychological Contract Breach over time was positively associated with increased feelings of violation, which subsequently was positively associated with increased CWB-O over time (Griep,Vantilborgh, and Jones, 2018). Psychological Contract Breach caused reduced job satisfaction, lower organizational commitment, decreased loyalty and reduced willingness to defend the organization, and increased turnover intention (Kraak, Lunardo, Herrbach, and Durrieu, 2016). 


\section{Theoretical Gaps of CWB}

Many typologies of Counterproductive Work Behavior (CWB) were enlisted in an attempt to describe CWB's diversities at workplace (Aube, Rousseau, Mama, and Morin, 2009). Some typologies were heavily lean towards labeling CWB as simply as deviant behavior. Though it is consistent with symmetric view as it comprises of all detrimental behaviors believed to have negative implications to employees and organizations. But using symmetric lens to understand CWB will deprive researchers in understanding how and why these negative behaviors were organized (Aube, Rousseau, Mama, and Morin, 2009). On the other hand, work deviant behavior defined by Warren (2003) consisting of constructive comformity, which refers to the case when reference group norms are in agreement with hyper norms, where both parties on transparency dealing; destructive conformity refers to the case of agreement with reference group norms, but disagreement with hyper norms such as free speech that is acceptable globally but is not acceptable within organization, with voice as one example; constructive deviance are conducts such as whistle blowing, that may go against organizational norms but are constructive in nature; and destructive deviance happens when there is a departure from both reference group norms and hyper norms, such as strike or protest (Hussain, Sia, and Mishra, 2014). Given differing perspectives in describing CWB, holistic understanding of CWB is essential in efforts to manage CWB.

Studies had shown linkages of psychological contract breach and disparate forms of CWB, such as voice behaviour (Guo, 2017); turnover intention (Kraak, Lunardo, Herrbach, and Durrieu, 2016); employees' unethical behavior (Ning and Zhaoyi, 2017); employee silence (Vakola and Bouradas, 2005) that may have denied an attentive understanding of employees' counterproductive work behavior in the context of employees' behavior in organization in distress. Furthermore, Spector et al's (2006) 45 items CWB measurement was initially considered. However, the absence of severity (Kelloway, Francis, Prosser, Cameron, 2010), with some CWBs that are underobserved and unaccounted for (Bennett and Robinson, 2000) that makes it unsuitable to be adopted in studies where understanding the absent workforce such as flight attendants, pilots, nurses, soldiers in coping within a distressed organization. The non-exhaustive list of counterproductive work behavior that could possibly fall under the definitions of CWB as well as differing perspectives in understanding CWB, may have undermined the need to provide a focused attention on employees' inclination to specific behaviors (positive and negative), worsen by employees' voicing mechanism that were immobilized. Thus, there is a gap in literature, to determine measurement for CWB suitable for use in organization in distress in the context of these absent workforce.

\section{Conceptualizing Counterproductive Work Behavior for this study}

Profession such as flight attendants, nurses, and shift workers rely heavily on their own independence, discipline, and emotional labor as argued by Bennet and Robinson (2000), which leads to many of CWBs being under-observed and unaccounted for (Raman, Sambasivan, and Kumar, 2016). In line with the understanding that the acts of CWB are nonexhaustive, and consistent with the aim of this study to understand how flight attendants react to airline that goes through distress leading to organizational changes, which helps this study to narrow down four anticipated reactions as proposed by Hirschman's Model of EVLN. This study serves to contribute to the existing body of knowledge by adapting Hirschman's typology of Reaction to Dissatisfaction, which is Exit, Voice, Loyalty, and Neglect with an 
extension of Acquiescent Silence as a better fit in anticipating dissatisfied flight attendants' alternative reactions when voicing mechanism such as strike or protest are immobilized. The following literature review will bring to an appreciation of how Hirschman's model of EVLN with an extension of acquiescent silence as one typology that falls under the general concept of CWB.

\section{Hirschman's Model of EVLN (1970)}

The theory of EVL (Exit, Voice, and Loyalty) by Hirschman (1970), with additional option, lax and disregardful behavior as identified by Koalrska \& Aldrich (1980); Rusbult et all (1982), completing the concept of EVLN (Exit, Voice, Loyalty, Neglect) model in response to job dissatisfaction (Farrel, 1983) proposed that dissatisfied employee have 4 options when they are dissatisfied with their job (Farrel, 1983). The primary study of EVLN focuses on employees' reaction to dissatisfaction, as claimed by Solinger et al (2008) and is categorized as active or passive, and constructive or destructive (Farrel, 1983). The findings of multidimensional analysis (MDSCAL) resulting a category of exit being active and destructive, voice as active and constructive, loyalty being passive and destructive, with neglect as passive and destructive (Farrel, 1983). Hirschman's Model of EVLN correspond with the general definition of CWB defined as employees' conduct that are damaging to colleagues and compromising the effectiveness of an organization (Klotz and Buckley, 2013). Daley (1992) claimed that many studies applied EVLN as dependent variables (Whitford and Lee, 2014), such as examining the relationship between psychological contract violation and EVLN (Turnley and Feldman, 1999).

This study review builds upon past researches using Hirschman (1970) and Rusbult et al (1983)'s refined framework of EVLN to understand the typology of four specific employees' reactions to dissatisfaction. Literatures relating to the four specific behaviors, exit, voice, loyalty, and neglect will each be reviewed to understand various reactions used by employees in relation to their undesirable work experiences. This is followed with the suggested alternative behavior, which is acquiescent silence.

\section{Exit - Turnover as a form of CWB}

Exit, is defined as "voluntary separation or turnover from a job" (Farrel, 1983). Employees may even opt for a transfer within the same company in response to stay away from a frustrating situation. Hirschman (1970) maintained that the motivation for an employee to resign or seek to transfer originate from a dreadful decision to withdraw or switch, knowing the troubled situation is doubtfully to improve (Farrel, 1983). Hirschman's exit may have attracted many scholars in using voluntary turnover and involuntary turnover interchangeably (Whitford and Lee, 2014). However, a person's expressed intention to leave helps to anticipate the actual turnover (Whitford and Lee, 2014).

Tett and Meyer (1993) defined turnover as a deliberated and conscious decision to leave the organization (Whitford and Lee, 2014). Turnover had often been used as a single exit option. However, it is proposed that turnover as a wider concept, consists of several exit options, namely retirement, moving to other agency, or outside the agency (Whitford and Lee, 2014). Rusbult, Farrel, Rogers and Mainus (1988) explained exit as employees' organizational 
behaviors reflected by job search intention, request for transfer, resign, or intention to resign (Yi and Li, 2011). Rusbult et al's (1988) work on behavioral responses to perceived inequity in the social exchange relationship, were predicted based on job satisfaction and quality of job alternatives (Thomas and Au, 2002).

Hirschman (1970, p.26) stated the "exit option may not lead to lost revenue if the firm are capable of attaining new customers or employees while losing the previous ones". Similarly, if an organization experiencing employee turnover, and the influx of new applicants are able to fill the gaps of those who left, this situation could lead to the organization overlooking the underlying factors that had forced the employees to exit. Hirschman continues to argue on the fact that while the organization's product or services deteriorate, the organization will still be able to attract new customers. Likewise, when the organization's working condition worsens, compelling the dissatisfied employees to quit, very likely there is a continuous supply of new employees who are more than eager to take on the job. This occurrence is best explained by "the similar quality decline that is affecting all organizations of the same industry" where a cyclical process is apparent from the movement of employees from firm to firm of the same industry, despite these firms' weaken performance (Hirschman, 1970, p.26).

What Hirschman (1970, p.50) termed as consumer (employee) surplus can be equated to how individual employees perceived themselves as having the affordability in terms of choice with options. Employees' surplus is also consistent with the pull and push factors as Sippola (2014) described in citizens or employees's attempt to exit the country or firm. The push factors can be explained by the unresolved discontentment triggered by the deteriorating firm, while the pull factors depend very much on the choices and options available for the employees to take on should he or she decides to exit. One example is how Estonia's 2004 accession to the EU had provided abundant opportunities for workers to seek employment abroad, the urge to work abroad were further intensified knowing Finland had abolished restrictions to free movement of labor in 2006 (Sippola, 2014). For Latvian workers, whose minimum wage was the lowest among the EU countries, the ease of emigration and the ample prospects in other developed countries such as Ireland and Britain had provided hope to these workers to move out of the worsening situation (Sippola, 2014).

In the case of flight attendants who are known for their critical role of executing the strategies laid down by management, hence, great investment is emphasized in the training of these employees (Chen, 2006). Due to the precarious working environment and towering stress level, the turnover of flight attendants are anticipated due to the effect of job dissatisfaction, declined normative and continuous commitment, not to mention the pay satisfaction and marital status factors that siginificantly influence their intention to leave the airline (Chen, 2006). As posited by Allen, Bryant, \& Vardaman (2010), employee turnover will cause organizations and managers to face continuous challenges given the reduced firm performance followed by talent loss, high cost in reselection, rehiring, and training (Wei, Li, and Kuvass, 2015).The reduction of flight attendants, due to turnover, apart from sickness absence, consequently will upset the carefully planned flight crew schedulling that had predetermined the minimum number of flight attendants for each flight. The failure in meeting the minimum number of flight attendants for a flight will cause delay as the airline 
has to comply to the Federal Aviation Association (FAA)'s ruling on minimum crew on board. Therefore, this example cast a picture of counterproductive work behavior of flight attendants that contribute to flight operation's disruption.

Naumann (1992) termed Turnover Intention as the separation of an employee from the organization (Rehman, Karim, Rafiq, and Mansoor, 2012). Factors contributing towards employee's turnover intention include Mohammad et al's (2006) on organizational commitment to turnover, Tan et al's (2006) study on job satisfaction, stress to turnover intention (Rehman, Karim, Rafiq, and Mansoor, 2012). This study calls for an expansion of the Hirschman's exit model, by operationalizing the exit concept through the use of turnover intention. Study conducted in Sweden had use turnover intention as an indicator of exit in a study of white-collar workers (Berntson, Naswall, and Sverke, 2010). Supporting the reliance on behavioral intention is Ajzen (1991) who describes intended behavior as "the subjective probability that is assigned by an individual to the likelihood that he or she will choose a given behavioral alternative" (Alleyne, 2016). Hence, it is within the scope of this study to understand the surviving flight attendants' turnover intention, as opposed to those flight attendants who had resigned, transferred, terminated, and those who are being offered exit packages.

Linking employee's psychosocial factors and turnover intention, Farrel et al (1983) and Rusbult et al (1988) asserted that there are three distinct factors believed to have strong influence in the way employee response to unfavorable work conditions, in accordance to EVLN model. Factors include the extent of investment to the job, the satisfaction level of the job, and the characteristics and availability of job alternatives (Lee and Jablin, 1992). Investment as described by Rusbult et al (1988) include "investments an employees put forth in his job such as the time and years spent in the specific position or organization, the established network built within the organization, colleagues, as well as familiarity with work and procedures, the non-tranferable skills and expertise acquired from training, the accumulated retirement funds and benefits and concessions gained over the years that could only be possible through the continued employment, such as travelling benefits to employee and extended family, housing arrangement, loan flexibility offered by financial institution given employees' association with the organization (Lee and Jablin, 1992). Employees' reaction to dissatisfaction as proposed by Hirschman's (1970) EVLN model, is assumed to be able to correct the causes of grievances through "exit" or "voice". However, a qualitative case study conducted by Sexsmith, K (2016) on migrant farm workers on New York dairies had suggested otherwise as any attempt by the dairy farm workers to exit or voice are constrained by structural forces. These were explained by the weak employment protection, stern immigration enforcement, and remoteness of dairy farm accentuate workers' mobility to leave the farm or to effectively voice out their predicaments (Sexsmith, 2016).

Study in Sweden with white-collar workers applying Hirschman's EVLN model, indicated respondents' perceived higher employability providing them more options to either exit, voice out, or to remain loyal. Employable individuals are individuals who hold significant position in the organization (Berntson, Naswall, and Sverke, 2010). This is explained by Hirschman's (1970, p.51) rationale of high quality-conscious customer or employees who 
would instantaneously choose exit over voice, given the availability of better quality substitutes, despite paying at a higher price. An individual who perceived to be more employable in the job market would opt to leave the deteriorating firm than to spend their time in voicing out to the deteriorating firm, which they perceived is in a situation that is beyond repair. Once again, Hirschman assumes that employees are free to decide whether to leave or to voice out (Sexsmith, 2016). While "exit" being considered as the first option, as suggested by Hirschman (1970), flight attendants who had devoted their time in an airline, though dissatisfied and felt a sense of deprivation, have to put enormous amount of consideration before making the extensive move of exiting the airline. The availability of comparable alternative as Hirschman (1970) claimed, will either dissuade or intensify flight attendants' intention to leave.

\section{Voice}

Hirschman (1970) further stated that voice will be the next alternative when exit is not a choice (Sexsmith, 2016). The concept of voice is the opposite of exit, as this "messy concept" as Hirschman termed it, can be found from a simple grumbling to violent protest (Hirschman, 1970). Hirschman explains that the usage of voice is "costly in terms of resources and time". Voice is further defined by Hirschman (1970) as efforts to change the situation rather than avoiding from the worsening situation (Farrel, 1983). It involves appeal or demand to higher authorities such as communicating problems with colleagues and supervisors, or to higher managerial hierarchy within the organization or turning outward by sharing their grievances with outside channel (Yi and \& Li, 2011). Rusbult et al (1988) claimed that voice is one way of obtaining assistance from an outside representative such as union or whistle-blowing (Lee and Jablin, 1992). This may also include actions such as protest (Farrel, 1983).

\section{Voice through Protest}

Protest is defined as a form of collective action (Stekelenberg and Klandermans, 2010). Studies in the past on collective action and social activism refers to structural and functionalist tradition, where the focus of issues were on labor, class, and the nation (Parvanova and Pichler, 2013). Caouette \& Tadem (2013) stated that global phenomena and local politics present two entities that cannot be seen apart. This can be viewed from the behaviors of local activist who drew upon international circulation discourses of labor rights and adapt into the local political context (Parvanova and Pichler, 2013).

\section{Protest is CWB}

CWB is viewed as a form of protest where individuals and groups's attempt to restore and express dissatisfaction with organizational events (Kelloway, Francis, Prosser, Cameron, 2010). Related examples include sabotage, a protest behavior in the early days of industrial revolution, in protesting objectionable work conditions by chucking the wooden shoes into the machinery to put the operation to a halt (Kelloway, Francis, Prosser, Cameron, 2010). Strike, is another form of protest which is considered as an intentional act that targets the organization (CWB-O). Strike militancy is defined as an intended behavior, which serves as one component of attitude. Past studies on militancy, had focused partly on striking (Deckop, McClendon, and Harris-Pereles, 1993). Threatened strike is further decribed as intended behavior of individuals who are prepared to be involved in the proposed strike (Bacharach, Bamberger, \& Conley, 1990; Martin, 1986), and their willingess to picket (Bacharach, 1990). 
Hicks $(1932,1963)$ described strike as an economic phenomenon (Malo and Sanchez-Sanchez, 2014). It is worthy to know that protest as employees' voice depends very much on the climate of protest in one's firm or states. Klanderman's (1993) theory of social movement explain the three elements to motivate employees to participate in such a risky endeavor. Apart from being aggrieved, employees must know that there is an efficacious channel that could represent them and speak on their behalf (Klandermans, 1993). These could be in the form of trade unions and labor demonstration, and the existence of legislation that do not term protest as being illegal. The successful creation of Attac France is one example of how the combination of aggrieved citizens, together with the entrepreneurs with resources in time, financial, energy, and experience, and the structural characteristics of the political system that made it possible for the creation of a social movement organization (Stockemer, 2011). The amalgamation of aggrieved individuals or groups, an efficacious channel such as union, and the right to strike guaranteed by the Constitution of France (Stewart and Bell, 2008) provide an explanation of the frequent strikes that took place in France. In contrast, for Lithuanians, though citizens were dissatisfied, the belief that their voice through protest will bring more risk than benefits, and the fact that Lithuania is one country that has the strictest anti-strike legislation among the FSU countries (Sippola, 2014) makes it even more impossible for a social movement organization to exist or sustain. A 2008 survey conducted on Lithuanian society by Civil Empowerment Index indicated $50 \%$ of respondents were not confident in strike action, given the implication on loss jobs, being openly attacked, and defamed (Sippola, 2014).

There were few attempted strikes by flight attendants of international carrier in Malaysia. The first incident happened on $14^{\text {th }}$ February 1979 (Matthews, 2013) and a union call for a "tool down" protest in response to anticipated job loss (The Star Online, 2015). The strike law climate in Malaysia, is leaned towards restraining the freedom of this common law as opposed to encouraging it (Cyrus, 1990). While freedom to strike remains "extant-namely", there are procedures that must be fulfilled or the strike can be considered unlawful, thereby the idea of freedom to strike in Malaysia should be understood as favoring the view of compulsory labor arbitration (Cyrus, 1990), which explains the scarce occurrences of employees' strike in Malaysia, given the limited freedom on public display of dissatisfaction. However, while legislation of strike in Malaysia is in place persuading the concept of compulsory labor arbitration as opposed to freedom to strike, the increasing awareness of worker's protection provides a contradictory plea from employees' perspective which is cited as saying that "what is viewed as employees' misconduct should not be a reason to deprived them their rights as workers, freedom of expression, and other human rights. Employees should be protected through a thorough outline of employment misconducts, which include their freedom to organizing, union building, as well as union activities" (Aliran, 2014).

It was further noticed that Rusbult's (1988) work did not incorporate societal and cultural context in which the exchange was embedded (Thomas and Au, 2002). Citing Schwartz's (1994) view that the economic, legal, and political systems which come under the societal context are visible manifestations of a more fundamental set of shared meanings. On the other hand, societal culture reflects the institutions of society, and is represented in a relatively stable values, attitudes, and behavioral assumptions of individuals (Thomas and $\mathrm{Au}, 2002)$. Hence, the understanding of societal and cultural context may shed light to the 
different countries' stance on strike. In Europian Union, however, the right to strike is protected under international and European human rights treaties, and is acknowledged as an important aspect of collective bargaining, and an imperative channel enabling workers to preserve their financial and social interest (Velyvyte, 2015). Supported by social psychology's stance that emphasized people in similar circumstances may respond variedly (Stekelenberg and Klandermans, 2010).

The impact of airline restructuring of Malaysia Airlines Berhad necessitates dissolving trade unions, and it is replaced with work council as employee's alternate communication channel (MTUC, 2015). Employees are suggested to experience challenges especially where they do not have any union voice (O'Sullivan and Gunnigle, 2009). Taking into consideration of the absence of employee union, and the perceived scarce alternative in labor market that may have dissuade flight attendants from quitting from the airline, further explain the weak propensity of employees to indulge in risky activity such as strike, as this precarious action will only land the employees to immediate dismissal, such as four flight attendants were terminated for participating in a union rally (The Star Online, 2014). Therefore, while flight attendants of other airlines were able to exercise their voice through strike or protest, flight attendants of Malaysia Airlines Berhad some other airlines do not own similar liberty as their western and some eastern counterparts. This serves as a gap to understand what other alternatives these flight attendants may resort to in expressing their discontentment given their constrained voicing mechanism.

\section{Voice through Whistle-blowing}

Near and Miceli (1985) defines whistle-blowing as employees' revelation of illegitimate practices within company to individuals or institutions capable to effect change (Alleyne, 2016). Whistle-blowing is said to share some common ground with the ethical voice, as both behaviors are based on moral motive and have possibilities of jeopardizing oneself due to his initiatives to defy the existing state of affairs (Lee, Choi, Youn, and Chun, 2017). Van Dyne et al (1995); Morrison (2011); and Liang et al (2012), indicate the difference between moral voice and whistle-blowing can be observed whereby whistle-blowing channel provides anonymity right to employees who pursued in disclosing information to parties outside of organization, whereas moral voice navigates employees to direct information within organization intended to improve one's organization (Lee, Choi, Youn, and Chun, 2017).

In a qualitative study involving 32 doctors and nurses from seven oncology units, study had offered an in-depth insight as to why the healthcare professionals' choice in choosing voice and silence. Results had shown that the barriers to speaking up outweighed the motivation to speak up (Schwappach and Gehring, 2014). Barriers include erosion of trust, fear of humiliating the actor, hierarchical structures, time constraint, fear of negative consequences, occupational group constellation, futility and resignation (Schwappach and Gehring, 2014). The choice to speak up or voice out or to remain silence were often persuaded by the trade-offs that comes together with voicing out or to remain silent (Schwappach and Gehring, 2014). 


\section{Voice through Speaking Up}

Mowbray, Wilkinson, \& Tse (2015) are referred describing employee voice behavior as one important channel organization can gain wisdom from employees (Guo, 2017). While Hirschman defines voice as a plea to higher authorities within or outside of the organization through the channel of union, or whistle blowing, Lepine and Van Dyne (2001) define employee's voice behavior as a promotive and challenging form of proactive behavior involving productive communication that oriented towards the urge to change to improve the situation. Van Dyne \& Lepine (1998) further described voice behavior as traditionally a challenging extra-role behavior (Wu, Tang, Dong, and Liu, 2015). Van Dyne et al. (2003) further defined voice as individuals' expressions of opinions and concerns that are intentional, exhibited by individuals, aimed to change the status quo, and are fueled by constructive and prosocial motives (Lin and Johnson, 2015).

Conversely, voice behavior can also be viewed as in-role activity or responsibility through role definition and role breadth ( $\mathrm{Wu}$, Tang, Dong, and Liu, 2015). The characteristics of employees' voice as described by Lepine and Van Dyne include the non-prescription of voice in the job description, and not being formalized in the reward system. Voice is defined as both constructive or destructive response, varying from initiating formal complaints and spreading negative information to discussing problems and providing suggestions (Aravopoulou, Mitsakis, and Malone, 2017). It was argued that employees will go through calculated and deliberated behavior after weighing the potential risk and benefits in their cognition. In other words, employee will consider to speak up only when the potential benefits outweigh the potential risk (Wu, Tang, Dong, Liu, 2015).

\section{Loyalty}

Loyalty, on the other hand, is characterized by their action to remain in the organization where they experience deteriorating working conditions (Farrel, 1983). As described by Hirschman (1970, p.38), those loyalist "suffer in silence, confident that things will soon get better" (Farrel, 1983, p.598). Loyalty can also be understood as effort to remain in the organization with the hope that situation will improve, while professing support to the organization, or observing good citizenship (Yi and Li, 2011). Hirschman's definition of loyalty was suggested as inadequately grasp the subtleties of loyalist behavior (Farrel, 1983). The EVLN model was suggested as not having the ability to explain the various reactions to dissatisfaction (Farrel, 1983) Suggestions to include abnormal events, such as accidents and sabotage that were proposed to be other forms of responses to dissatisfaction (Farrel, 1983). Given the complexity in discerning Hirschman's concept of loyalty, therefore it has been operationalized in various concepts. Withey \& Cooper (1989) citing Hagedoorn \& colleagues' rationale of renaming loyalty to patience (Naus, Iterson, and Roe, 2007); loyalty was regarded as "forced false loyalty" (Sippola, 2014), or "constrained loyalty and entrapment" (Sexsmith, 2016). On the other hand, Hirschman's definition of loyalty whereby employees remain loyal but suffer in silence is consistent with the findings of multidimensional analysis on EVLN describing loyalty as destructive and passive (Farrel, 1983). Therefore, when employees perceived lesser employability due to age and sunk cost will not resort to turnover, neither will they resort to voicing out due to the high initiation cost of voice (Farrel, 1983). Employees who feel that it is too risky to uproot themselves, and "the effect of bad alternatives on exits" (Farrel, 1983) consistent with Hirschman's claim that "loyalist behavior 
retains an enormous dose of reasoned calculation" (Farrel, 1983, p. 598) will choose to stay in the deteriorating firm, and silently enduring their job dissatisfaction.

Given the increased awareness of the risks exposed to flight attendants, why do employees still remain in the industry? Citing Lu et al (2008) that work devotion exhibited by employees are explained by their tolerance of the job risks as "necessary evils" in exchange for an insurance for job security (Dai, Chen, and Zhuang, 2015). Apart from the physiological job risk exposed to this group of aviation workers, this study suggests that there are likely underlying psychosocial hazards and benefits specific to flight attendants' job to explain long tenured flight attendants in the airline (Hazaz-Berger and Yair, 2011). While earlier studies may have been disoriented merely by the word "loyalty" as it does not reflect the expected behavior of dissatisfied employees, a deeper appreciation of "loyalty" from the context of Hirschman's model will help to clarify that "loyalty" meant by Hirschman is merely as an employee attached with an employee number. In line with the concept of Counterproductive Work Behavior, loyalty is operationalized as "disloyalty" in this review which is defined as no loyalty, and being associated with disengaged, disturbed, disenchanted, and disruptive (Rowley and Dawes, 2000). The concept of Disloyalty is supported by several authors, namely Osborne, Smith, and Huo (2012), applying Hirschman's EVLN model, whereby individual relative deprivation was claimed to be negatively associated with loyalty, and Psychological Contract Breach caused reduced loyalty, and less willingness to defend the organization (Kraak, Lunardo, Herrbach, and Durrieu, 2016).

\section{Neglect}

Neglect, defined by Kolarska and Aldrich (1980) as silence and inaction; characterized by Rusbult et al (1982) as the absence of compassion and lack of caring and alienation. Neglect is generally defined as employees' predisposition towards "lax and disregardful behavior" or careless and disdain behavior (Farrel, 1983, p. 598). Rusbult et al (1988) further defined neglect as "submissively allow situations to get worse through diminished enthusiasm, effort, leading to persistent tardiness and increased absenteeism" (Lee and Varon, 2016, p.3). In one meta-analysis determining the association between withdrawal and CWB, results had indicated that withdrawal and CWB are strongly related, with relationship between withdrawal and CWB targeting organization (CWB-O) is especially strong (Carpenter and Berry, 2017). When employees are left with no option to exit due to high investment and nonavailability of better job alternatives, when voice options are perceived to be non-efficacious, and when employees choose to remain in a worsening situation, they are suggested to submit to the state of neglect (Farrel, 1983).

\section{Acquiescent Silence as a form of CWB}

The fact that EVLN model does not exhaust the possible responses, and expanding the model is highly encouraged (Farrel, 1983), motivate this study to the usage of acquiescent silence in explaining employees' another behavioral alternative in respond to deteriorating work condition. Silence is defined as withholding opinion about own evaluative and affective judgements towards work condition to someone who is known to be capable to effect change (Pinder and Harlos, 2001). Flesch (1957) and Bruneau (1973) describe silence as an expression of all kinds of intense emotions which include fear, surprise, anger, love (Pinder and Harlos, 2001). Pinder and Harlos (2001) maintained that silence and voice are used by 
employees to indicate their eargerness or unwillingeness to participate in organizational initiatives and implementation (Schlosser and Zolin, 2012). Voice is suggested to have positive effects (Schlosser and Zolin, 2012), consistent with Hirschman's definition of voice as being active and constructive (Farrel, 1983). Silence, on the contrary, is known for its negative effects (Schlosser and Zolin, 2012). Silence can be viewed as defensive silence, a premeditated and intentional and proactive behavior that is aimed to secure oneself from external threats (Schlosser and Zolin, 2012). Van Dyne et al (2003) further maintained that the distinct difference between voice and silence "is not the presence or absence of speaking up, but the drive to express versus withhold ideas, information, and opinions on workrelated improvements" (Schlosser and Zolin, 2012).

Schlosser and Zolin (2012) listed many reasons employees choose to remain silent, which include the concern of being regarded in a damaging way, hurting valued relationship, damaging their professional reputation, and the repercussion of speaking up on their future promotion and career path. Van Dyne et al (2003) suggested that defensive silence is driven by the need to protect oneself manifested by fear (Schlosser and Zolin, 2012). Pinder and Harlos (2001) highlighted Hirschman's work, which had placed strength on exit and voice, but little regards were given to silence. An employee who choose to remain silent, does not necessarily indicate his or her agreement to what has been suggested by the decision makers as silence can also be a sign of withdrawal (Harlos and Knoll, 2018). The concept of acquiescent silence, consistent with Pinder and Harlos's (2001) which is based on futility and resignation (Harlos and Knoll, 2018). Acquiescent silence is described as harmful to organizations, as claimed by Morrison and Milliken (2000) due to its potentiality in inhibiting organizational change, citing Tangirala and Ramanujan (2008); Van Dyne et al., (2003), further defined acquiescent silence as having the capability in subduing the initiatives in improving organizational performance (Erkutlu and Chafra, 2018). This is in line with the general definition of counterproductive work behavior, which is defined as "workers' behavior that are harmful, thus reduce the effectiveness of an organization (Klotz and Buckley, 2013).

\section{Summary}

Literature review thus far brings to the understanding of Counterproductive Work Behavior that could easily be understood as merely a deviant behavior (Kelloway, Francis, Prosser, Cameron, 2010), given its harmful repercussion leading to distressing overall operational efficiency (Anjum and Parvez, 2013). Nevertheless typologies such as symmetric and asymmetric (Reynolds, Shoss, and Jundt, 2015) and constructive or destructive (Hussain, Sia, and Mishra, 2014) where the outcome of CWB can also be seen as good or bad for different stakeholder (Reynolds, Shoss, and Jundt, 2015) highlight the need to look beyond the simple notion of CWB as being deviant, by navigating researchers to understand the reasons behind these behaviors given that CWB is described as an occurrence of multifaceted phenomenon that results from various antecedents (Hussain, Sia, and Mishra, 2014). Additionally, using Hirschman's Model of EVLN with an extension of acquiescent silence in response to job discontentment, provides an avenue for scholars to address the infinite list of counterproductive work behaviors that were highlighted in the past by narrowing down to five specific behaviors flight attendants may resort to in response to dissatisfaction, worsen by immobilized voicing mechanism. Lastly, while not discounting other possible reactions to 
dissatisfaction (Farrel, 1983), understanding counterproductive work behavior from Hirschman's Model highlights the existence of not merely tangible but intangible and underobserved behaviors of absent workforce such as flight attendants, which are not easily captured through organization's formal communication channel but are potentially detrimental if not given due attention.

\section{References}

Aliran. (2014). Aliran.com. Retrieved September 12, 2017, from Aliran: https://aliran.com/civil-society-voices/2014-civil-society-voices/worker-trade-unionrights-must-prioritised-well-workers-families/

Alleyne, P. (2016). The Influence of Organizational Commitment and Corporate Ethical Values on Non-Public Accountants' Whistle-Blowing intentions in Barbados. Journal of Applied Accounting, 17(2), 190-210.

Anjum, M. A., and Parvez, A. (2013). Counterproductive Behavior at Work: A comparison of Blue Collar and White Collar Workers. Pakistan Journal of Commerse and Social Sciences, 7(3), 417-434.

Aravopoulou, E., Mitsakis, and Malone, C. (2017, July). A Critical Review of the Exit-VoiceLoyalty-Neglect Literature: Limitations, Key Challenges and Directions for Future Research. The International Journal Of Management (IJM), 6(3), 1-10.

Aube, C., Rousseau, V., Mama, C., and Morin, E. M. (2009). Counterproductive Behaviors and Psychological Well-being: The Moderating Effect of Task Interdependence. Journal of Business Psychology, 24, 351-361.

Bacharach, S. B., Bamberger, P., and Conley, S. C. (1990, May). Work processes, role conflict, and role overload: The case of Nurses and Engineers in the Public Sectors. Work and Occupations, 17(2), 199-228.

Bai, Q. Y., Lin, W. P., and Wang, L. (2016). Family incivility and counterproductive work behavior: A moderated mediation model of self esteem and emotional regulation. Journal of Vocational Behavior, 94, 11-19. doi:10.1016/j.jvb.2016.02.014

Bennett, R. J., and Robinson, S. L. (2000). Development of a measure of workplace deviance. The Journal of Applied Psychology, , 85(3), 349-360.

Berntson,E., Näswal, K., and Sverke, M. (2008). Investigating the relationship between employability and self-efficacy: A cross-lagged analysis. European Journal of Work and Organizational Psychology, 17, 413-425.

Brimecombe, M., Magnusen, M. J., and Bunds, K. (2013). Navigating the Storm: A Counterproductive work behavior and leadership case study in a Division 1 FBS School. Sports Management Review, 17, 209-237. Retrieved from http://dx.doi.org/10.1016/j.smr.2013.03.001

Carpenter, N. C., and Berry, C. M. (2017). Are Counterproductive Work Behavior and Withdrawal Empirically Distinct? A Meta- Analytic Investigation. (D. 10.1177/0149206314544743, Ed.) Journal of Management, 43(3), 834-863.

Chen, C. F. (2006). Job satisfaction, organizational commitment, and flight attendants' turnover intention. Journal of Air Transport Management, 274-276.

Cohen, A. (2016). Are they among us? A conceptual framework of the relationship between the dark triad personality and counterproductive work behaviors (CWBs). Human Resource Management Review, 26, 69-85. Retrieved from http://dx.doi.org/10.1016/j.hrmr.2015.07.003 
Cyrus, V. D. (1990). The Control and Regulation of Strikes and Lockouts in Malaysia. 2nd International Seminar on Labour Law (pp. 96-108). LAWASIA Standing Committee on Labour Law.

Dai, Y. D., Chen, K. Y., and Zhuang, W. L. (2015). Moderating effect of work-family conflict on the relationship between leader-member exchange and relative deprivation: Links to behavioral outcomes. Tourism Management, 54, 369 - 382.

Deckop, J. R., McClendon, J. A., and Harris-Pereles, K. L. (1993). The Effect of Strike Militancy Intention and General Union Attitudes on the Organizational Citizenships of University Faculty. Employee's Responsibilities and Rights Journal, 6(2).

Dischner, S. (2015). Organizational structure, organizational form, and counterproductive work behavior: A competitive test of the bereaucraatiooc and post-bureaucratic views. Scandinavian Journal of Management, 31, 501-514. Retrieved from http://dx.doi.org/10.1016/j.scaman.2015.10.002

Erkutlu, H., and Chafra, J. (2018). "Leader's integrity and employee silence in healthcare organization. Leadership in Health Services, 1751-1879. doi:https://doi.org/10.1108/LHS-03-2018-0021

Farrel, D. (1983, Dec). Exit, Voice, Loyalty, and Neglect as Responses to Job Dissatisfaction. Academy of Management Journal, 26(4), 596-607.

Fatima, A., Atif, Q.M., Saqib, A.,and Haider, A. (2012). A Path Model Examining the Relations among Organizational Injustice, Counterproductive Work. International Journal of Innovation, Management and Technology, Vol. 3, No. 6, December 2012, 3(6). doi:DOI: 10.7763/IJIMT.2012.V3.322

Griepa, Y., and Vantilborgh, T. (2018). Reciprocal effects of psychological contract breach on counterproductive and organizational citizenship behaviors: The role of time. (http://dx.doi.org/10.1016/j.jvb.2017.10.013, Ed.) Journal of Vocational Behavior, 104, 141-153.

Guo, Y. (2017). Effect of Psychological Contract Breach on Voive Behavior: Evidence From China. (https://doi.org/10.2224/sbp.6326, Ed.) Social Behavior and Personality, 45(6), 1019-1028.

Harlos, K., Knoll, M. (2018). Employee Silence and Workplace Bullying. In D. P. (eds), Pathways of Job-related Negative Behaviour: Handbooks of Workplace Bullying, Emotional Abuse and Harassment, (Vol. 2, pp. 1-29). Singapore: Springer. doi:https://doi.org/10.1007/978-981-10-6173-8_9-1

Hazaz-Berger, H., and Yair, G. (2011). The Social Structure of the Liquid Self: Exploratory Lessons from Israeli Flight Attendants. Sociology.

Hirschman, A. O. (1970). Exit, Voice, and Loyalty: Responses to decline in firms, organizations, and states. London: Harvard University Press.

Hussain, I., Sia, S. K., and Mishra, P. K. (2014). Workplace deviance and the menace of some antecedents: A review of extant literature. Indian Journal of Helath and Wellbeing, 5(7), 13-20.

Kelloway, E. K., Francis, L., Prosser, M., Cameron, J. E. (2010). Counterproductive Work Behavior as Protest. Human Resource Management Review, 20, 18-25.

Klandermans, B. (1993). A Theoretical Framework for Comparisons of Social Movement Participation. Sociological Forum, 8(3), 383-402.

doi:https://doi.org/10.1007/BF01115051 
Klotz, A. C., and Buckley, M. R. (2013). A Historical Perspective of Counterproductive work behavior targeting the organization. Journal of Management History, 19(1), 114-132.

Kraak, J. M., Lunardo, R., Herrbach, O., and Durrieu, F. (2016). Promises to employees matter, self-identity too: Effects of psychological contract breach and older worker identity on violation and turnover intentions. Journal of Business Research , 1-10.

Kret, M. E., Denollet, J., Grezes, J., and Gelder, B. D. (2011). The Role of Negative Affectivity and Social Inhibition in perceiving Social Threat: An fMRI study. Neuropsychologia, 49, 1187-1193.

Lee, D., Choi, Y. D., Youn, S., and Chun, J. U. (2017). Ethical Leadership and Employee Moral Voice: The Mediating Role of Moral Efficacy and the Moderating Role of LeaderFollower Value Congruence. (CrossMark, Ed.) Journal of Business Ethics, 47-57.

Lee, J., and Jablin, F. M. (1992). A Cross-Cultural Investigation of Exit,Voice, Loyalty and Neglect as Responses to Dissatisfying Job Conditions. The Journal of Business Communication, 29(3), 203-228.

Lee, J., \& Varon, A. L. (2016). Employee Exit, Voice, Loyalty, and Neglect in Response to Dissatisfying Organizational Situations. , 232948841667583. International Journal of Business Communication, 1-22. doi:doi:10.1177/2329488416675839

Lin, S. H., and Johnson, R. E. (2015, February 23). A Suggestion to Improve a Day Keeps Your Depletion Away: Examining Promotive and Prohibitive Voice Behaviors Within a Regulatory Focus and Ego Depletion Framework. Journal of Applied Psychology, 1-16.

Malo, M. A., and Sanchez-Sanchez, N. (2014). The Legal Form of Labour conflicts and Their Time Persistence: An Empirical Analysis With A Large Firm's Panel. European Journal of Law Economic , 38, 513-533.

Marcus, B., and Schuler, H. (2004). Antecedents of Counterproductive Behavior at Work: A General Perspective. (0.-9. D. 10.1037/0021-9010.89.4.647, Ed.) Journal of Applied Psychology, 89(4), 647-660.

Matthews, P. (2013). Chronicle of Malaysia (1963-2013) Fifty Years of Headline News. (J. Sharmila, Ed.) Malaysia: EDM Edition Didium Millet.

MTUC. (2015). MAS Act unjust to workers and trade unions. (Malaysian Trade Union Congress) Retrieved May 7, 2018, from mtuc.org.my: http://www.mtuc.org.my/masact-unjust-to-workers-and-trade-unions/

Naus, F., Iterson, A. V., and Roe, R. (2007, May). Organizational cynicism: Extending the exit, voice, loyalty, and neglect model of employees' responses to adverse conditions $i$ the workplace. Human Relations, 683-718.

Ning, N., and Zhaoyi, L. (2017). Psychological Contract Breach, Organizational Disidentification, and Employees' Unethical Behavior: Organizational Ethical Climate as Moderator. (https://doi.org/10.2224/sbp.6708, Ed.) Social Behavior and Personality, 45(9), 1409-1424.

O'Sullivan, M., and Gunnigle, P. (2009, June). "Bearing All the Hallmarks of Oppression" Union Avoidance in Europe's Largest Low-cost Airline. (D. 1. OAI, Ed.) Labor Studies Journal, 34(2).

Parvanova, D., and Pichler, M. (2013). Activism and Social Movements in South East Asia. 6(1), pp. 1-6.

Pinder, C. C., and Harlos, K. P. (2001). Employee Silence: Quiescence and Acquiescence as Responses to Perceived Injustice. Research in Personnel and Human Resources Management, 20, 331-369. 
Podsakoff, P. M., Mackenzie, P. M., Moorman, R. H., and Fetter, R. (1990). Transformational Leaders Behaviors and Effects on Followers' Trust in Leader, Satisfaction, and Organizational Citizenship Behavior. Leadership Quarterly, 1(2), pp. 108-142.

Raman, P., Sambasivan, M., and Kumar, N. (2016). Counterproductive work behavior among frontline givernment employees: Role of personality, emotional intelligence, affectivity, emotional labor, and emotional exhaustion. Journal of Work and Organizational Psychology, 1-13. Retrieved from http://dx.doi.org/10.1016/j.rpto.2015.11.002

Rehman, O., Karim, F., Rafiq, M., and Adil, M. (2012). The mediating role of organizational commitment between emotional exhaustion and turnover intention among customer service representative . African Journal of Business Management, 6(34).

Reynolds, C. A., Shoss, M. K., and Jundt, D. K. (2015). In the eye of the beholder: A multistakeholder perspective of organizational citizenship and counterproductive work behaviours. Human Resource Management Review, 25, 80-93. Retrieved from http:dxdoi.orh/10.1016/j.hrmr.2014.06.002

Rowley, J., and Dawes, J. (2000). Disloyalty: A Closer Look at Non-Loyals. Journal of Consumer Marketing, 17(6), 538-549.

Sayers, J. K., Sears, K. L., Kelly, K. M., and Harbke, C. R. (2011). When Employee Engage in Workplace Incivility: The Interactive Effect of Psychological Contract Violation and Organizational Justice. Employ Response Rights Journal, 23, 269-283.

Scherer, K. T., Baysinger, M., Zolynsky, D., and LeBreton, J. M. (2013). Predicting counterproductive work behaviours with sub-clinical psychopathy: Beyong the Five Factor Model of personality. Personality and Individual Differences, 55, 300-305. Retrieved from http://dx.doi.org/10.1016/j.paid.2013.03.007

Schlosser, F., and Zolin, R. (2012). Hearing Voice and Silence During Stressful Economic Times. Employee Relation, 34(5), 555-573.

Schwappach, D. L. B., and Gehring, K. (2014). Trade-offs between voice and silence: A qualitative exploration of oncology staff's decisions to speak up about safety concerns. BioMed Central Health Services Research, 303.

Sexsmith, K. (2016). Exit, Voice, Constrained loyalty, and Entrapment: Migrant farmworkers and the expression of discontent on New York dairy farms. Citizenship Studies, 1-12.

Shahnawaz, M. G., and Goswami, K. (2011). Effect of Psychological Contract Violation On organizational Commitment, Trust, and Turnover Intention in Public Sector Indian Organizations. The Journal of Business Perspective , 15(3), 209-217.

Sippola, M. (2014, October 13). The Awkward Choices Facing the Baltic Worker: Exit or Loyalty. Journal of Baltic Studies, 44(4), 451-473.

Stekelenberg, J.V., and Klandermans, B. (2010). The Social Psychology of Protest. Sociopedia.isa, 1-13.

Stewart, A., and Bell, M. (2008). The Right to Strike: A Comparative Perspective. The Institute of Employment Rights, 1-107.

Stockemer, D. (2011). The Successful Creation of Attac France: The Role of Structure and Agency. French Politics, 9(2), 120-138.

The Star Online. (2015, June 12). All MAS staff offered jobs at new airline must decide by $5 p m$ today. Retrieved from www.thestar.com.my: https://www.thestar.com.my/news/nation/2015/06/12/to-accept-or-not-to-acceptall-mas-staff-offered-jobs-at-new-airline-must-decide-by-5pm-today/ 
Thomas, D. C., and Au, K. (2002). The Effect of Cultural Differences on Behavioral Responses to Low Job Satisfaction. Journal of International Business Studies, 33(2), 309.

Turnley, W. H., and Feldman, D. C. (1999). "The Impact of Psychological Contract Violations on Exit, Voice, Loyalty, and Neglect". Human Relations, 52(7), 895.

Vakola, M., and Bouradas, D. (2005). Antecedents and consequences of organisational silence: an empirical investigation . (D. 10.1108/01425450510611997, Ed.) Employee Relations, 27(5), 441-458.

Velyvyte, V. (2015, March). The Right to Strike in the European Union after Accession to the European Convention on Human Rights: Identifying Conflict and Achieving Coherence. Human Rights Law Review, 15(1), 73-100. doi:10.1093/hrlr/ngu041

Warren, D. E. (2003). Constructive and Destructive Deviance in Organizations. Academy of Management Review, 622-632.

Wei, Li, R. L., and Kuvass, B. (2015). Workgroup Salary Dispersion and Turnover Intention in China: Contingent Examination of Individua Differences and The Dual Deprivation Path Explanation. (P. o. (wileyonlinelibrary.com)., Ed.) Human Resource Management.

Whitford, A. B., and Lee, S. Y. (2014, February 13). Exit, Voice, and Loyalty with Multiple Exit Options: Evidence from the US Federal Workforce. Journal of Public Administration and Theory Advance.

Wu, W., Tang, F., Dong, X., and Liu, C. (2015). Different identifications cause different types of voice: $A$ role identity approach to the relations between organizational socialization and voice. Asia Pacific Journal Management, 251-287.

Yi, S., and \& Li, Y. (2011, July 18). Human Resource Management Practices on Exit, Voice, Loyalty, and Neglect: Organizational Commitment as a Mediator. The International Journal of Human Resource Management, 23(8), 1705-1716. 